\title{
Recommended standards for the description of new species of anoxygenic phototrophic bacteria
}

Correspondence

Johannes F. Imhoff jimhoff@ifm-geomar.de

\author{
Johannes F. Imhoff ${ }^{1}$ and Pierre Caumette ${ }^{2}$ \\ ${ }^{1}$ Institut für Meereswissenschaften, Düsternbrooker Weg 20, D-24105 Kiel, Germany \\ ${ }^{2}$ Laboratoire d'Ecologie Moléculaire, Microbiologie, EA 3525, Université de Pau, F-64000 Pau, \\ France
}

\begin{abstract}
Recommended standards for the description of new species of the anoxygenic phototrophic bacteria are proposed in accordance with Recommendation $30 \mathrm{~b}$ of the International Code of Nomenclature of Bacteria. These standards include information on the natural habitat, ecology and phenotypic properties including morphology, physiology and pigments and on genetic information and nucleic acid data. The recommended standards were supported by the Subcommittee on the taxonomy of phototrophic bacteria of the International Committee on Systematics of Prokaryotes. They are considered as guidelines for authors to prepare descriptions of new species.
\end{abstract}

\section{Introduction}

Four major phenotypically and phylogenetically welldistinguished groups of bacteria are able to perform anoxygenic photosynthesis and to grow phototrophically under anoxic conditions. These are the Chlorobiales (green sulfur bacteria), the 'Heliobacteriaceae' (classified as Clostridiales), the 'Chloroflexales' (green filamentous bacteria) and the phototrophic purple bacteria belonging to the $\alpha$-, $\beta$ - and $\gamma$-Proteobacteria. The separation of these groups is well documented not only on the basis of $16 \mathrm{~S}$ rDNA sequences, but also by a number of distinct phenotypic properties.

The most important common property of these bacteria is the possession of photosynthetic pigments, which is visible in their light-absorption spectra, and a photosynthetic apparatus, which enables the performance of lightdependent energy generation. With the exception of some of the phototrophic Proteobacteria, the so-called aerobic bacteriochlorophyll-containing bacteria (ABC bacteria; Shiba, 1992), they are anaerobic bacteria performing anoxygenic photosynthesis under anoxic conditions in the light. Generally, pigment biosynthesis and formation of the photosynthetic apparatus are suppressed by oxygen and regulated by the light intensity (again in contrast to the $\mathrm{ABC}$ bacteria). However, in regard to pigment structure and composition, to structural features of the photosynthetic apparatus and to major biochemical pathways, the four groups show marked differences.

The current classification is based on nucleic acid analyses ( $\mathrm{G}+\mathrm{C}$ content, $16 \mathrm{~S}$ rDNA sequences and, in some cases, also DNA-DNA relatedness) and on phenotypic properties such as physiology, growth characteristics, morphology and pigment composition. During the last few years, a fairly complete database of $16 \mathrm{~S}$ rDNA sequences of available type strains (and additional other strains) of the species of Chlorobiaceae (Overmann \& Tuschack, 1997; Alexander et al., 2002), purple sulfur bacteria (Imhoff \& Süling, 1996; Guyoneaud et al., 1998; Imhoff et al., 1998), green filamentous bacteria (Keppen et al., 2000), 'Heliobacteriaceae' (Bryantseva et al., 1999, 2000; Madigan, 2001) and purple non-sulfur bacteria (Hiraishi \& Ueda, 1994; Hiraishi et al., 1995; Imhoff et al., 1998; Kawasaki et al., 1993) has been built up. These data have revealed the phylogenetic relationships of these bacteria based on 16S rDNA sequences and are used today to determine the phylogenetic position of novel isolates. In addition, $16 \mathrm{~S}$ rDNA-based sequence information has been used to reconsider the relative importance that is given to several phenotypic properties used in the taxonomic classification of phototrophic bacteria (see Imhoff et al., 1998; Imhoff, 1999).

\section{General Comments}

Recommended standards for the description of new species of the anoxygenic phototrophic bacteria are proposed in accordance with Recommendation $30 \mathrm{~b}$ of the International Code of Nomenclature of Bacteria (the Bacteriological Code; Lapage et al., 1992). The purpose of these recommendations is to provide a framework for taxonomic studies of anoxygenic phototrophic bacteria and the description of new species. With the support of the Subcommittee on the taxonomy of phototrophic bacteria of the International Committee on Systematics of Prokaryotes, we recommend the inclusion of phenotypic, genotypic and ecological properties for the description of new species of these bacteria. It should be emphasized that most of the recommended data are essential for a species description to be accepted 
for publication, while others are not obligatory and a few are optional, although they are valuable and important criteria for describing properties of phototrophic bacteria. The essential characters are marked in bold and the optional ones are indicated as such in Table 1.
The description of new species or subspecies of the anoxygenic phototrophic bacteria should be based on sufficient information to differentiate a new taxon from existing species of the genus. It should rely on a wide variety of phenotypic and molecular properties and their experimental

Table 1. Characteristics required for the description of new species of anoxygenic phototrophic bacteria

Properties shown in bold are essential for the description of a new species; others are highly recommended. Those marked as optional provide possibly important properties of the bacterium but are not regarded as essential for the species description.

\begin{tabular}{|c|c|}
\hline Property & Comments \\
\hline \multicolumn{2}{|l|}{ Morphology: } \\
\hline \multicolumn{2}{|l|}{ Cell shape ${ }^{a_{\star}}$} \\
\hline \multicolumn{2}{|l|}{ Cell size (diameter, length) ${ }^{a}$} \\
\hline \multicolumn{2}{|l|}{ Motility $^{a}$ and flagellation ${ }^{b}$} \\
\hline \multicolumn{2}{|l|}{ Type of cell division ${ }^{b}$} \\
\hline \multicolumn{2}{|l|}{ Cell differentiation and life cycle } \\
\hline Formation of typical cellular aggregates ${ }^{a}$ & e.g. Net or platelet formation, capsule and slime formation \\
\hline Visible internal or external structures ${ }^{b}$ & e.g. Spores, gas vesicles \\
\hline Gram-stain $^{a}$ & Optional in the case of established Proteobacteria \\
\hline Ultrastructure $^{c}$ & e.g. Internal membranes, chlorosomes and others \\
\hline \multicolumn{2}{|l|}{ Chemical composition: } \\
\hline \multicolumn{2}{|l|}{ Colour of cell suspensions } \\
\hline \multicolumn{2}{|l|}{ In vivo absorption spectra } \\
\hline \multicolumn{2}{|l|}{ Type of bacteriochlorophyll } \\
\hline Carotenoids & Optional \\
\hline Quinones & Optional \\
\hline Fatty acids & Optional \\
\hline Reserve materials & e.g. $\mathrm{PHB}$, polyglucose, $S^{0}$ \\
\hline DNA base ratio & i.e. $\mathrm{G}+\mathrm{C}$ content \\
\hline Phylogenetic analysis & 16S rDNA sequence, phylogenetic tree position \\
\hline DNA-DNA hybridization & If applicable \\
\hline Cell wall analysis & Optional \\
\hline \multicolumn{2}{|l|}{ Physiology: } \\
\hline \multicolumn{2}{|l|}{ Growth medium } \\
\hline \multicolumn{2}{|l|}{ Temperature range and optimum } \\
\hline \multicolumn{2}{|l|}{$\mathrm{pH}$ range and optimum } \\
\hline \multicolumn{2}{|l|}{$\mathrm{NaCl}$ range and optimum } \\
\hline \multicolumn{2}{|l|}{ Vitamin requirements } \\
\hline \multicolumn{2}{|l|}{ Carbon, nitrogen and sulfur sources } \\
\hline Relation to sulfide & Tolerance, use, oxidation products \\
\hline Relation to oxygen & Anaerobic, aerobic, microaerobic growth, tolerance \\
\hline Light responses & Minimum requirement, light sensitivity: optional \\
\hline \multicolumn{2}{|l|}{ Modes of energy generation: } \\
\hline \multicolumn{2}{|l|}{ Phototrophy } \\
\hline \multicolumn{2}{|l|}{ Potential chemotrophy } \\
\hline \multicolumn{2}{|l|}{ Electron donors } \\
\hline \multicolumn{2}{|l|}{ Electron acceptors } \\
\hline \multicolumn{2}{|l|}{ Ecology: } \\
\hline Natural habitat & Physico-chemical properties, $\mathrm{pH}$, salinity, temperature \\
\hline Source of isolates & Geographical location, GPS positioning \\
\hline Mineral salts composition of source & \\
\hline Abundance at habitat & \\
\hline
\end{tabular}

${ }^{\star}$ To be demonstrated by: $a$, a light micrograph; $b$, a light or electron micrograph; $c$, an electron micrograph. 
comparison with the most similar described species. It is proposed that the placement of a new species or genus should preferentially be consistent with its phylogenetic position according to $16 \mathrm{~S}$ rDNA nucleotide sequences and, if possible, to other gene sequences (optional). It is recommended that several isolates, preferably from independent sources, should be included in these studies, whenever possible. The different sources and environments should be indicated and major characteristics thereof should be described. However, when a single strain has been retrieved from a unique source or has important and unique properties, it may be described as a new species, if the description is of such detail to ensure significant differences from all known members of phylogenetically related species.

The achievement of obtaining pure cultures, including media and growth conditions, and the methods used to prove purity should be described. A type strain has to be designated for the new species and needs to be deposited in at least two permanent culture collections (Rule 18 of the Bacteriological Code). The type strains of related species should be included in the study and differentiating characteristics thereof compared to the new species.

The description of new species should be published in a journal of wide distribution, preferably in the International Journal of Systematic and Evolutionary Microbiology (IJSEM). When published in another journal, a reprint should be submitted to the IJSEM so that the name of the new species may be validated. If the requirements of the Bacteriological Code have been met, it will be included in the Validation List of this journal as demanded by the Bacteriological Code (Lapage et al., 1992).

Putative new species of uncultured organisms for which molecular sequence data such as 16S rDNA nucleotide sequences are available may qualify for the status 'Candidatus' (Murray \& Schleifer, 1994; Murray \& Stackebrandt, 1995). It is required that at least three sequences from different sources are provided that form a coherent cluster in phylogenetic analyses. An important requirement of the 'Candidatus' status is that the proposed organism is identified with a specific probe by in situ hybridization techniques. In addition to sequence data, morphological properties and, if possible, other characteristic features should be supplied.

\section{Recommended Standards}

\section{Ecology}

The natural habitat and its geographical location of the proposed new species should be described in as much detail as possible. It should include the $\mathrm{pH}$, temperature range, salinity and mineral salts composition. The GPS positioning should also be included. If possible, information on the bacterial abundance and distribution at the natural habitat should be included as well as knowledge of the occurrence in different habitats.

\section{Phenotypic characterization}

Guidelines for the phenotypic description of phototrophic bacteria are found in various publications and it is recommended to refer to the chapters of Bergey's Manual of Systematic Bacteriology for properties of relevance for the differentiation from related species. It is proposed to use the characters described below and summarized in Table 1 as features for the description of new species of anoxygenic phototrophic bacteria. Different growth media are required for the proper cultivation of the different physiological types of phototrophic bacteria. Compilations of media useful for their culture are given in chapters of The Prokaryotes and Bergey's Manual (Imhoff, 1992b; Imhoff \& Trüper, 1992; Madigan, 1992; Pfennig \& Overmann, 2001; Pfennig \& Trüper, 1992; Pierson \& Castenholz, 1992; Pierson, 2001) and by Imhoff (1992a). Media used for isolation and growth need to be described precisely in their composition and preparation, or references should be given. It is necessary that basic conditions for optimum growth (responses to $\mathrm{pH}$, temperature, salinity, light and oxygen) are reported. They should be established before other phenotypic properties of the isolates are determined, in order to ensure that these tests are performed at the optima of these basic parameters.

\section{Cell morphology}

The properties of colony and cell morphology should be determined under optimum $\mathrm{pH}$, temperature, light and salt concentration. The medium and culture conditions under which these properties were determined have to be described. Cell morphology should be studied by phasecontrast microscopy of exponentially growing liquid cultures. The shape and size, the staining behaviour in the Gram-stain, the type of cell division, any special morphological properties (presence of flagella, formation of cell aggregates, slime, capsules, cellular inclusions, spore formation) and motility of the cells have to be reported.

Gas vesicles are formed by a number of phototrophic bacteria and can easily be recognized under the light microscope. However, the property to form gas vesicles may depend on the culture conditions and may be lost by some strains. Therefore, not much weight should be given to the presence or absence of gas vesicles in taxonomic decisions. Specific culture conditions that initiate the formation of gas vesicles should be given.

Negative stains under electron microscopic observation can be used to supply information on the presence and location of flagella. Care has to be taken, however, because flagella may be lost by some bacteria quite easily during long-term cultivation after several transfers in synthetic media and this can lead to non-motile forms of basically motile bacteria. It is therefore important to perform microscopic examination of cultures in various growth stages and under different culture conditions and to observe motility under the microscope. Electron microscopic examination of thin sections is required to demonstrate the presence 
and form of internal membrane structures, of chlorosomes and other characteristic morphological features (gas vesicles, spores).

\section{Colour of cell suspensions and absorption spectra}

The colour of cell suspensions and in vivo light-absorption spectra from 370 to $1020 \mathrm{~nm}$ are indicative of the type and chemical structure of major photosynthetic pigments and have to be reported. An in vivo absorption spectrum needs to be published together with the species description. Absorption spectra of whole cells are measured with cell suspensions washed twice in medium or appropriate salt solutions and then suspended in $60 \%(\mathrm{w} / \mathrm{v})$ sucrose solution (Biebl \& Drews, 1969). Better results are often achieved by using isolated photosynthetic membranes suspended in buffer. For this purpose, it is sufficient to break the cells by ultrasonication or with a French press and to separate whole cells and large cell fragments from the internal membranes by centrifugation at $15000 \mathrm{~g}$. In some cases, light-absorption spectra of pigments after methanol or acetone/methanol extraction under anoxic conditions are necessary for identification of bacteriochlorophylls. It should be noted that the specific chemical identity of carotenoids cannot be delineated from absorption spectra and that more sophisticated chemical analyses are required to identify these pigments. Therefore, a qualitative and quantitative detailed pigment analysis is an optional property for the description of a new species.

\section{Physiological properties}

The exact composition of the culture medium used for growth experiments and the culture conditions in regard to $\mathrm{pH}$, temperature, light and salinity for all nutritional tests have to be included in the species description. Factors affecting growth should be investigated under conditions as close as possible to the optimum of other growth factors and need to be described in detail. Growth experiments and determination of physiological properties should be performed at least in triplicate in liquid medium under anoxic conditions and in the light. They include ranges and optima of $\mathrm{pH}, \mathrm{NaCl}$ concentration and temperature, light, vitamin requirements and utilization of carbon, nitrogen and sulfur sources, $\mathrm{H}_{2}$ utilization, as well as the presence of nitrogenase and catalase.

Conditions of growth should also include the relations to oxygen. Qualitatively, these relations may be most easily determined in agar tubes set up with a suitable anoxic medium, inoculated and carefully mixed with a well-grown culture; the tubes are exposed to the air at the top to allow oxygen to diffuse into the agar and to establish an oxygen gradient. By incubation both in the light and in the dark, first hints on the response of the isolate to oxygen under both conditions can be visualized, i.e. possible microaerobic respiratory growth in the dark (chemotrophy) and tolerance of oxygen and possible microaerobic phototrophic growth in the light. Similar experiments can also be used to determine the effect of oxygen on the synthesis of photosynthetic pigments.

\section{Nutrition}

Because of the widely differing nutritional properties of different groups of anoxygenic phototrophic bacteria, the determination of their nutritional properties has to consider the different growth capabilities. Therefore, the major groups are treated separately below.

Order Chlorobiales. The Chlorobiales, with the Chlorobiaceae as the only family, are strictly anaerobic and phototrophic bacteria. Photoautotrophic growth in the presence of sulfide, sulfur, thiosulfate, sulfite and hydrogen with $\mathrm{CO}_{2}$ as sole carbon source should be verified in the presence of possible growth factors (vitamin $\mathrm{B}_{12}$ and possibly others). Photoassimilation of acetate, propionate, formate, lactate, glycerol, pyruvate, succinate, fumarate, malate, glucose and other sugars should be analysed. The utilization of different nitrogen sources should be investigated (including ammonia, nitrate, glutamine and possibly other amino acids, optionally dinitrogen). The vitamin requirements (vitamin $B_{12}$ and others) should be established.

Phototrophic purple bacteria. Photoautotrophic growth in the presence of sulfide, sulfur, thiosulfate, sulfite and hydrogen with $\mathrm{CO}_{2}$ as sole carbon source should be analysed in the presence of possible growth factors. Photoheterotrophic growth (in the absence of an inorganic electron donor) and the assimilation of organic substrates in the presence of an inorganic photosynthetic electron donor (sulfide, sulfur, thiosulfate, hydrogen) should be examined. Substrates to be tested are: sulfide $(0 \cdot 5-3 \mathrm{mM})$, sulfur $(0 \cdot 1 \%)$, thiosulfate $(5 \mathrm{mM})$, sulfite $(0.5 \mathrm{mM})$, formate $(2 \mathrm{mM})$, acetate, propionate, butyrate, valerate, crotonate, citrate (all $5 \mathrm{mM})$, caprylate $(2 \mathrm{mM})$, pelargonate $(2 \mathrm{mM})$, palmitate $(2 \mathrm{mM})$, lactate $(5 \mathrm{mM})$, pyruvate $(5 \mathrm{mM})$, succinate, malate, fumarate (all $5 \mathrm{mM}$ ), oxoglutarate, benzoate $(2 \mathrm{mM})$, tartrate $(5 \mathrm{mM})$, nicotinate $(2 \mathrm{mM})$, glucose $(5 \mathrm{mM})$, fructose $(5 \mathrm{mM})$, sucrose $(5 \mathrm{mM})$, trehalose $(5 \mathrm{mM})$, glycolate $(5 \mathrm{mM})$, glutamate, aspartate, gluconate (all $5 \mathrm{mM})$, methanol $(5 \mathrm{mM})$, ethanol $(5 \mathrm{mM})$, propanol $(5 \mathrm{mM})$, butanol $(5 \mathrm{mM})$, mannitol (5 $\mathrm{mM})$, glycerol $(5 \mathrm{mM})$, glycine betaine $(5 \mathrm{mM})$, peptone $(0 \cdot 05 \%)$, cysteine $(2 \mathrm{mM})$, methionine $(2 \mathrm{mM})$, thioglycolate $(2 \mathrm{mM})$, thioacetamide $(2 \mathrm{mM})$, Casamino acids $(0.05 \%)$ and yeast extract $(0.05 \%)$. Recommended concentrations are indicated in parentheses. Growth with additional substrates may be analysed according to the physiological capacities of the bacteria under investigation.

In addition, the utilization of different nitrogen sources should be analysed (including ammonia, nitrate, glutamine and possibly other amino acids, optionally dinitrogen). The vitamin requirements should be examined, in particular of vitamin $B_{12}$ in purple sulfur bacteria and a number of vitamins in the purple non-sulfur bacteria. 
Order 'Chloroflexales'. Photoautotrophic growth with sulfide or hydrogen and $\mathrm{CO}_{2}$ as sole carbon source should be verified in the presence of possible growth factors (yeast extract or mixtures of vitamins). Both photoheterotrophic (anoxic light conditions) and chemoheterotrophic (oxic dark conditions) growth of those representatives presently in culture occurs best in the presence of yeast extract (and Casamino acids). Experiments of carbon sources utilized should include glycerol, acetate, formate, glucose (and other sugars), glutamate, aspartate, pyruvate, lactate, ethanol, succinate, malate, fumarate, propionate and butyrate (in the presence of growth factors; $0.01 \%$ yeast extract and/or vitamins). Vitamin requirements (biotin, vitamin $\mathrm{B}_{12}$ and others) as well as the utilization of different nitrogen sources should be tested (including ammonia, nitrate, glutamine and possibly other amino acids, optionally dinitrogen).

Family 'Heliobacteriaceae'. Heliobacteria are strictly anaerobic, photoheterotrophic bacteria. Photoautotrophic growth (although not found so far in 'Heliobacteriaceae') and photoheterotrophic growth with a variety of carbon sources (including pyruvate, lactate, acetate, propionate, butyrate and ethanol) should be investigated in the absence and presence of $\mathrm{CO}_{2}$. In addition, growth with yeast extract and casamino acids as carbon sources should be analysed. Also, the ability to grow under chemo-organotrophic conditions anaerobically as well as anaerobically (e.g. fermentation of pyruvate) should be established. Vitamin requirements (biotin and others) should be tested and growth should be established whenever possible in the absence of complex nutrients. Sulfide, thiosulfate, sulfate and cysteine or methionine should be established as possible sulfur sources. The utilization of different nitrogen sources should be analysed (including ammonia, nitrate, glutamine and other amino acids, optionally dinitrogen).

\section{Lipid and fatty acid composition}

The lipid and fatty acid composition of phototrophic bacteria is quite useful in the characterization of different species and groups of phototrophic bacteria (Imhoff, 1991; Imhoff \& Bias-Imhoff, 1995; Thiemann \& Imhoff, 1996). Fatty acid composition can be determined by gas chromatography using standard methods. Polar lipid patterns can be determined by one- or two-dimensional thin-layer chromatography (Imhoff et al., 1982; Imhoff, 1991). Information on fatty acids and polar lipids is considered as optional.

\section{Nucleic acid characterization}

The description of new species of anoxygenic phototrophic bacteria needs to contain information on the G+C content of their DNA and the nucleic acid sequence of the $16 \mathrm{~S}$ rDNA (more than $1200 \mathrm{nt}$ ). The DNA base composition may be determined by any of the commonly used techniques, such as ultracentrifugation in a $\mathrm{CsCl}$ gradient, thermal denaturation or HPLC of nucleotides after hydrolysis. Reference DNA (e.g. Escherichia coli ATCC $11775^{\mathrm{T}}$ : $51 \mathrm{~mol} \% \mathrm{G}+\mathrm{C}$ ) should be included in the analyses and the method used has to be given with the description.

The 16S rDNA nucleotide sequence is considered important to give information on the phylogenetic position of novel isolates. Sequences should be determined for representative strains included in the study. If a greater number of strains is available, alternative methods (e.g. genomic fingerprints) may be used to demonstrate the heterogeneity within the species and the differentiation from other species. Sequences need to be deposited with a recognized database. The database records and publications must include correct statements of the identity of the source strain. The accession numbers must be given together with the species description. The sequences of molecules other than 16S rDNA (such as puf gene sequences or others) may provide important additional phylogenetic information and should be included in considerations whenever possible. The sequences of fmo genes of the Chlorobiaceae, for example, have substantiated the phylogeny of this group as established by $16 \mathrm{~S}$ rDNA sequences (Alexander et al., 2002).

The description of the methods used for alignment and the algorithms for tree construction should be included in the species description. Phylogenetic trees should be constructed using different methods, e.g. maximum-likelihood and distance-based methods. The reliability of the branching should be evaluated statistically by bootstrap analysis.

The discrimination of closely related species of the same genus should be demonstrated by DNA-DNA relatedness studies. DNA-DNA relatedness studies can be used to assess relationships only within narrow ranges of variation, because relatedness values fall to low levels (less than $30 \%$ ) for phenotypically moderately different species. By and large, values of more than $70 \%$ DNA-DNA relatedness and differences in the denaturation temperatures of homoand heteroduplexes of less than $5^{\circ} \mathrm{C}$ should be used as criteria for species recognition according to Wayne et al. (1987). Hybridization studies should include several strains of the newly proposed species, including the proposed type strain, as well as type strains of related species. DNA-DNA hybridization studies are required to ensure species identity when $16 \mathrm{~S}$ rDNA sequences reveal similarities of more than $97 \%$ (sequence similarity of more than $97 \%$ does not necessarily mean identity at the species level). DNA-DNA hybridization has not been widely used in studies of anoxygenic phototrophic bacteria (e.g. de Bont et al., 1981; Ivanova et al., 1985; Ventura et al., 2000). If the hybridization level is above $70 \%$, a new species generally should not be proposed.

\section{References}

Alexander, B., Andersen, J. H., Cox, R. P. \& Imhoff, J. F. (2002). Phylogeny of green sulfur bacteria on the basis of gene sequences of 
$16 \mathrm{~S}$ rRNA and of the Fenna-Matthews-Olson protein. Arch Microbiol 178, 131-140.

Biebl, H. \& Drews, G. (1969). Das in-vivo Absorptionsspektrum als taxonomisches Merkmal bei Untersuchungen zur Verbreitung von Athiorhodaceae. Zentbl Bakteriol Parasitenkd Infektionskr Hyg 123, 425-452 (in German).

Bryantseva, I., Gorlenko, V. M., Kompantseva, E. I., Imhoff, J. F., Süling, J. \& Mityushina, L. (1999). Thiorhodospira sibirica gen. nov., sp. nov., a new alkaliphilic purple sulfur bacterium from a Siberian soda lake. Int J Syst Bacteriol 49, 697-703.

Bryantseva, I. A., Gorlenko, V. M., Kompantseva, E. I. \& Imhoff, J. F. (2000). Thioalkalicoccus limnaeus gen. nov., sp. nov., a new alkaliphilic purple sulfur bacterium with bacteriochlorophyll $b$. Int J Syst Evol Microbiol 50, 2157-2163.

de Bont, J. A. M., Scholten, A. \& Hansen, T. A. (1981). DNA-DNA hybridization of Rhodopseudomonas capsulata, Rhodopseudomonas sphaeroides and Rhodopseudomonas sulfidophila strains. Arch Microbiol 128, 271-274.

Guyoneaud, R., Süling, J., Petri, R., Matheron, R., Caumette, P., Pfennig, N. \& Imhoff, J. F. (1998). Taxonomic rearrangements of the genera Thiocapsa and Amoebobacter on the basis of $16 \mathrm{~S}$ rDNA sequence analyses, and description of Thiolamprovum gen. nov. Int J Syst Bacteriol 48, 957-964.

Hiraishi, A. \& Ueda, Y. (1994). Intrageneric structure of the genus Rhodobacter: transfer of Rhodobacter sulfidophilus and related marine species to the genus Rhodovulum gen. nov. Int J Syst Bacteriol 44, 15-23.

Hiraishi, A., Urata, K. \& Satoh, T. (1995). A new genus of marine budding phototrophic bacteria, Rhodobium gen. nov., which includes Rhodobium orientis sp. nov. and Rhodobium marinum comb. nov. Int J Syst Bacteriol 45, 226-234.

Imhoff, J. F. (1991). Polar lipids and fatty acids in the genus Rhodobacter. Syst Appl Microbiol 14, 228-234.

Imhoff, J. F. (1992a). Taxonomy, phylogeny and general ecology of anoxygenic phototrophic bacteria. In Biotechnology Handbook Photosynthetic Prokaryotes, pp. 53-92. Edited by N. G. Carr \& N. H. Mann. London \& New York: Plenum.

Imhoff, J. F. (1992b). The family Ectothiorhodospiraceae. In The Prokaryotes. A Handbook on the Biology of Bacteria. Ecophysiology, Isolation, Identification, Applications, 2nd edn, pp. 3222-3229. Edited by A. Balows, H. G. Trüper, M. Dworkin, W. Harder \& K. H. Schleifer. New York: Springer.

Imhoff, J. F. (1999). A phylogenetically oriented taxonomy of anoxygenic phototrophic bacteria. In The Phototrophic Prokaryotes, pp. 763-774. Edited by G. A. Pescheck, W. Löffelhardt \& G. Schmetterer. New York: Plenum.

Imhoff, J. F. \& Bias-Imhoff, U. (1995). Lipids, quinones and fatty acids of anoxygenic phototrophic bacteria. In Anoxygenic Photosynthetic Bacteria, pp. 179-205. Edited by R. E. Blankenship, M. T. Madigan \& C. E. Bauer. Dordrecht: Kluwer.

Imhoff, J. F. \& Süling, J. (1996). The phylogenetic relationship among Ectothiorhodospiraceae: a reevaluation of their taxonomy on the basis of 16S rDNA analyses. Arch Microbiol 165, 106-113.

Imhoff, J. F. \& Trüper, H. G. (1992). The genus Rhodospirillum and related genera. In The Prokaryotes. A Handbook on the Biology of Bacteria. Ecophysiology, Isolation, Identification, Applications, 2nd edn, pp. 2141-2155. Edited by A. Balows, H. G. Trüper, M. Dworkin, W. Harder \& K. H. Schleifer. New York: Springer.

Imhoff, J. F., Kushner, D. J., Kushwaha, S. C. \& Kates, M. (1982). Polar lipids in phototrophic bacteria of the Rhodospirillaceae and Chromatiaceae families. J Bacteriol 150, 1192-1201.

Imhoff, J. F., Süling, J. \& Petri, R. (1998). Phylogenetic relationships among the Chromatiaceae, their taxonomic reclassification and description of the new genera Allochromatium, Halochromatium, Isochromatium, Marichromatium, Thiococcus, Thiohalocapsa and Thermochromatium. Int J Syst Bacteriol 48, 1129-1143.

Ivanova, T. L., Turova, T. P. \& Antonov, A. S. (1985). DNA-DNA and rRNA-DNA hybridization studies in the genus Ectothiorhodospira and other purple sulfur bacteria. Arch Microbiol 143, 154-156.

Kawasaki, H., Hoshinoi, Y. \& Yamasato, K. (1993). Phylogenetic diversity of phototrophic purple nonsulfur bacteria in the Proteobacteria alpha group. FEMS Microbiol Lett 112, 61-66.

Keppen, O. I., Tourova, T. P., Kuznetsov, B. B., Ivanovsky, R. N. \& Gorlenko, V. M. (2000). Proposal of Oscillochloridaceae fam. nov. on the basis of a phylogenetic analysis of the filamentous anoxygenic phototrophic bacteria, and emended description of Oscillochloris and Oscillochloris trichoides in comparison with further new isolates. Int J Syst Evol Microbiol 50, 1529-1537.

Lapage, S. P., Sneath, P. H. A., Lessel, E. F., Skerman, V. B. D., Seeliger, H. P. R. \& Clark, W. A. (editors) (1992). International Code of Nomenclature of Bacteria (1990 Revision). Bacteriological Code. Washington, DC: American Society for Microbiology.

Madigan, M. T. (1992). The family Heliobacteriaceae. In The Prokaryotes. A Handbook on the Biology of Bacteria. Ecophysiology, Isolation, Identification, Applications, 2nd edn, pp. 1981-1992. Edited by A. Balows, H. G. Trüper, M. Dworkin, W. Harder \& K. H. Schleifer. New York: Springer.

Madigan, M. T. (2001). Family VI. "Heliobacteriaceae" Beer-Romero and Gest 1987, 113. In Bergey's Manual of Systematic Bacteriology, 2nd edn, vol. 1, pp. 625-626. Edited by D. R. Boone, R. W. Castenholz \& G. M. Garrity. New York: Springer.

Murray, R. G. E. \& Schleifer, K. H. (1994). Taxonomic notes: a proposal for recording the properties of putative taxa of procaryotes. Int J Syst Bacteriol 44, 174-176.

Murray, R. G. E. \& Stackebrandt, E. (1995). Taxonomic note: implementation of the provisional status Candidatus for incompletely described procaryotes. Int J Syst Bacteriol 45, 186-187.

Overmann, J. \& Tuschak, C. (1997). Phylogeny and molecular fingerprinting of green sulfur bacteria. Arch Microbiol 167, 302-309.

Pfennig, N. \& Overmann, J. (2001). Genus I. Chlorobium Nadson $1906,190^{\mathrm{AL}}$. In Bergey's Manual of Systematic Bacteriology, 2nd edn, vol. 1, pp. 605-610. Edited by D. R. Boone, R. W. Castenholz \& G. M. Garrity. New York: Springer.

Pfennig, N. \& Trüper, H. G. (1992). The family Chromatiaceae. In The Prokaryotes. A Handbook on the Biology of Bacteria. Ecophysiology, Isolation, Identification, Applications, 2nd edn, pp. 3200-3221. Edited by A. Balows, H. G. Trüper, M. Dworkin, W. Harder \& K. H. Schleifer. New York: Springer.

Pierson, B. K. (2001). Family I. "Chloroflexaceae". Filamentous anoxygenic phototrophic bacteria. In Bergey's Manual of Systematic Bacteriology, 2nd edn, vol. 1, pp. 427-429. Edited by D. R. Boone, R. W. Castenholz \& G. M. Garrity. New York: Springer.

Pierson, B. K. \& Castenholz, R. W. (1992). The family Chloroflexaceae. In The Prokaryotes. A Handbook on the Biology of Bacteria. Ecophysiology, Isolation, Identification, Applications, 2nd edn, pp. 3754-3774. Edited by A. Balows, H. G. Trüper, M. Dworkin, W. Harder \& K. H. Schleifer. New York: Springer.

Shiba, T. (1992). The genus Erythrobacter. In The Prokaryotes. A Handbook on the Biology of Bacteria. Ecophysiology, Isolation, Identification, Applications, 2nd edn, pp. 2485-2489. Edited by A. Balows, H. G. Trüper, M. Dworkin, W. Harder \& K. H. Schleifer. New York: Springer.

Thiemann, B. \& Imhoff, J. F. (1996). Differentiation of Ectothiorhodospiraceae based on their fatty acid composition. Syst Appl Microbiol 19, 223-230. 
Ventura, S., Viti, C., Pastorelli, R. \& Giovanetti, L. (2000). Revision of species delineation in the genus Ectothiorhodospira. Int J Syst Evol Microbiol 50, 583-591.
Wayne, L. G., Brenner, D. J., Colwell, R. R. \& 9 other authors (1987). Report of the ad hoc committee on reconciliation of approaches to bacterial systematics. Int J Syst Bacteriol 37, 463-464. 